Jadila: Journal of Develomment and Innovation

in Language and Literature Education

Volume 1 Number 12020

Publisher: Yayasan Karinosseff Muda Indonesia

Page 57-68

\title{
Types of Lexical Cohesion and Grammatical Cohesion in Thesis Abstracts
}

\author{
Rena Puspa Kirana \\ University of Bengkulu \\ renakirana86@gmail.com \\ Mukhrizal \\ University of Bengkulu \\ mukhrizal@unib.ac.id \\ Fernandita Gusweni Jayanti \\ University of Bengkulu \\ fernandita.gusweni@gmail.com \\ Corresponding author: renakirana86@gmail.com
}

\begin{abstract}
This research attempted at investigating the types of lexical cohesion and grammatical cohesion used in thesis abstracts composed by undergraduate English department students of Universitas Bengkulu and also the errors of using cohesion. The research was designed as a descriptive quantitative method. The corpus of this study was 30 thesis abstracts composed by undergraduate English department students of Universitas Bengkulu. The instrument of this research was self-developed checklist. In analyzing data, the researchers were using formula by Sugiono. The results of this research showed that : 1.) There were 458 as the total number of six lexical cohesion types found in 30 thesis abstracts and the most dominant type is Repetition (58.7\%). 2.) There were 783 as the total number of four grammatical cohesion types found in 30 thesis abstracts and the most dominant type is Reference (70.2\%). 3.) There were three errors of using cohesion namely omission of conjunction and selection of conjunction. Therefore, it was concluded that the thesis abstracts composed by undergraduate English department students of Universitas Bengkulu were in the percentage of $99.76 \%$ good.
\end{abstract}

Keywords : Grammatical Cohesion, Lexical Cohesion, Thesis Abstract.

\section{A. Introduction}

Discourse analysis is concern with the relation between language and the contexts. It grew out of work in different disciplines in the 1960s and early 1970s, including linguistics, semiotics, psychology, anthropology and sociology. Discourse analysts study language in use: written texts of all kinds, and spoken data, from conversation to highly institutionalised forms of talk (McCharty,1991). One example of discourse analysis is cohesion. Halliday and Hasan (1976) said that Cohesion is divided into two aspects, namely grammatical and lexical cohesion. Cohesion is useful in writing (Rahmawati, 2019), even it could be used in speaking because it is one of the parts in grammar which relates to the speaking (Syafryadin, et. al 2013; Noermanzah, et al. 2020; Syafryadin, et al., 2020). Grammatical cohesion consists of reference, ellipsis, substitution and conjunction. Then, lexical cohesion consists of reiteration and collocation. Those all devices are used to unite sentences in the discourse into the 
meaningful ones. According to Salkie (2001), Cohesion is an important textual aspect to achieve qualified writing.

Theoretically, the result of this study is expected to be useful for the next researchers who want to analyze the same topic. This error analysis of Cohesion Devices on the abstract thesis will give information about what types of cohesion devices are used in a text and the error of those cohesion devices in thesis abstract.

Practically, This study is expected to give more information to the students in developing their knowledge about the cohesion devices and improving their understanding in using cohesion devices to improve their ability in writing a cohesive text. This study also expected to give information about the common error of using cohesion devices in thesis abstract composed by undergraduate English students of Universitas Bengkulu.

There are so many research that investigate cohesion, they are Afful and Nartey (2014) underr the title "Cohesion in the Abstracts of Undergraduate Dissertations: An Intradisciplinary Study in a Ghanaian University”, Klimova and Hubackova (2014) under the title "Grammatical Cohesion in Abstracts", Malah (2015) under the title "Lexical cohesion in academic discourse: exploring applied linguistics research articles abstracts", Suwandi (2016) with the title "Coherence And Cohesion: An Analysis Of The Final Project Abstracts Of The Undergraduate Students of PGRI Semarang “, Almutairi (2017) "Discourse Analysis of Cohesive Devices in Saudi Student'sWriting", Gholami and Alizadeh (2017) "A Contrastive Study of Lexical Cohesion in Introduction in Research Articles: Native English and Iranian Applied Linguistics" and Nurman, Arsyad and Zahrida(2019) "Discourse Markers in Argymentative Essay by the English Education Study Program's Students of Universitas Bengkulu : A Cross-sectional Study”. However, all the studies that researchers mention above has been done in other countries or other city in Indonesia. And for the last one, althought Nurman has been done the reserach in Universitas Bengkulu, but she examines the other types of discourse analysis namely discourse marker, so this research will examine both lexical and grammatical cohesion.

In this study, the researchers analyzed the types and errors of using lexical and grammatical cohesion in abstract section of 30 theses composed by undergraduate English students of Universitas Bengkulu because abstract section are usually written by researcher themselves without any expert's opinion, so this allows the sentence to be more inappropriate or more ineffective. Therefore, the researchers interest in analyzing cohesive devices which 
used on abstract and its errors of undergraduate thesis in order to identify wheter the abstract has a good cohesive relation or not.

Based on the explanation above, the aims of this research are as follows : 1) To find out the types of lexical cohesion use in thesis abstract written by undergraduate English students of Universitas Bengkulu in the period 2017 to 2019. 2) To find out the types of grammatical cohesion use in thesis abstract written by undergraduate English students of Universitas Bengkulu in the period 2017 to 2019. 3) To find out if there any types of lexical cohesion and grammatical cohesion which undergraduate English students of Universitas Bengkulu in the period 2017 to 2019 use erroneously in their thesis abstract.

\section{B. Research Methodology}

This research used descriptive quantitative method. Quantitative is a type of research that is explaining a phenomena by collecting numerial data that are analyzed using mathematically based method (in particular statistic) (Cresswell,2002).Quantitative research deals with questions of relationship, cause and effect, or current status that researchers can answer by gathering and statistically analyzing numeric data (Ary,2010). According to Gay (1987), descriptive method is to find the answer of questions and to test hypothesis concerning the current situation of the subject of the research when there is certain phenomenon of situation happened.

The population of this study is 219 students which were graduated in 2017 to 2019 . According to Arikunto (2006), if the population is less than 100, it is better for the researcher to take all of them as sample. Meanwhile, if the population is more than 100, the researcher may take $10-15 \%$ or $20-25 \%$ of the total population. In this research, the researchers took $10-$ $15 \%$ of the total population so the corpus of this study is thirty students' undergraduate theses abstractof English Department of Universitas Bengkulu. The theses were taken randomly by the researchers.

Instrument of this research is a self-developed checklist based on Haliday \& Hasan (1976) and Platridge (2012) theory to find out the number of lexical and grammatical cohesion devices that used in thesis abstract composed by undergraduate English Students of Universitas Bengkulu in the period 2017 to 2019. To answer the third question, the researchers also used a checklist to analyzed the error of using cohesion devices. 
In collecting the data, the first technique which was used by the researchers were taking the undergraduate theses randomly. Secondly, the researchers read the thesis abstracts one by one. Thirdly, selected and classified the words that were appropriate with the theory. Then, analyzed the data from the researchers and co-rater.After that, the analysis continued by the researchers to get the rest of the data and the errors of each thesis abstracts. Lastly, made the conclusion based on the research.

To make sure the validity and reliability of the analysis, the researcher used a co-rater to validate the data. In this strategy, the two raters divided the data and analyze it independently, and then the result was compared. Percent Agreement as written by McHugh (2012) was used to measure the agreement of the two raters.

The concept of "agreement among raters" is fairly simple, and for many years interrater reliability was measured as percent agreement among the data collectors. To get the measure of percent agreement, the statistician created a matrix in which the columns represented the different raters and the rows represented variables for which the raters had collected data (McHugh, 2012). In this interrater reliability calculation, the reseacher took $80 \%$ as the minimum of percent agreement that was accepted as Good category.

\section{Results and Discussion}

\section{Results}

\section{Lexical Cohesion}

To make sure the validity and reliability of the analysis, the researcher used a co-rater to validate the data. In this case, both rater and co-rater has been analyzed ten thesis abstracts and the result of inter-rater reliability using percent agreement showed that in lexical cohesion, the average percentage of percent agreement is $83.3 \%$.Meanwhile, in grammatical cohesion, the average percentage of percent agreement is $97.5 \%$.

In this research, there are so many lexical cohesion devices found by the researcher in thesis abstract. The data obtained from 30 theses abstract written by English Department Students of Universitas Bengkulu. The data will be shown below :

Table 1 : Types of Lexical Cohesion Used in Thesis Abstract

\begin{tabular}{|c|c|c|c|}
\hline No & Lexical Cohesion & Total & Percentage \\
\hline 1 & Repetition & 269 & $58.7 \%$ \\
\hline
\end{tabular}




\begin{tabular}{|c|c|c|c|}
\hline 2 & Collocation & 64 & $14 \%$ \\
\hline 3 & Meronymy & 56 & $12.2 \%$ \\
\hline 4 & Hyponymy & 45 & $9.8 \%$ \\
\hline 5 & Antonymy & 12 & $2.6 \%$ \\
\hline 6 & Synonymy & 12 & $2.6 \%$ \\
\hline & Total & 458 & $100 \%$ \\
\hline
\end{tabular}

From the data, there are six types of lexical cohesion devices found by the researcher in 30 theses abstract written by English Department Students of Universitas Bengkulu. From the table above, we can see that Repetition is the item that the most often encountered by the researcher. As Platridge (2000) said, repetition refers to words that are repeated in the text, as well as words that have changed to reflect tense or number such as feel and felt (reflecting a change in tense) and feeling and feelings (reflecting a change in number).

\section{Grammatical Cohesion}

In this research, there are also so many grammatical cohesion devices found in 30 theses abstract. The data will be shown below :

Table 2 : Types of Grammatical Cohesion Used in Thesis Abstract

\begin{tabular}{|c|c|c|c|}
\hline No & Grammatical Cohesion & Total & Percentage \\
\hline 1 & Reference & 550 & $70.2 \%$ \\
\hline 2 & Conjunction & 228 & $29.1 \%$ \\
\hline 3 & Ellipsis & 4 & $0.51 \%$ \\
\hline 4 & Substitution & 1 & $0.13 \%$ \\
\hline & Total & 783 & $100 \%$ \\
\hline
\end{tabular}

From the data, there are four types of grammatical cohesion devices found by the researcher in 30 theses abstract written by English Department Students of Universitas Bengkulu. The most dominant item is reference which is encountered 550 times.

As Halliday and Hasan (1976) said :

Reference is the relation between an element of text and something else by reference to which it is interpreted in the given instance. Reference is a potentially cohesive relation because the thing that serves as the sources of the interpretation may itself be an element of a text. 


\section{Error in Using Cohesion}

In this research, the researcher also found some errors in using cohesion devices. As stated by Ellis (1997), There are four types of error. First type is omission. The author further stated that omission means leaving out an item that is needed to make the sentence correct. Second type is addition. Addition is adding unnecessary element into a sentence. Third type is selection, means error in selecting word in a sentence. Last type is misordering. He defined that misordering means putting the word in wrong order.

Table 3 : Errors in Using Cohesion

\begin{tabular}{|c|c|c|c|}
\hline No & Types of Error & Total & Percentage \\
\hline 1 & Omission & 2 & $66.6 \%$ \\
\hline 2 & Selection & 1 & $33.3 \%$ \\
\hline 3 & Addition & - & - \\
\hline 4 & Misordering & - & - \\
\hline \multicolumn{2}{|c|}{ Total } & $\mathbf{3}$ & $\mathbf{9 9 , 9 \%}$ \\
\hline
\end{tabular}

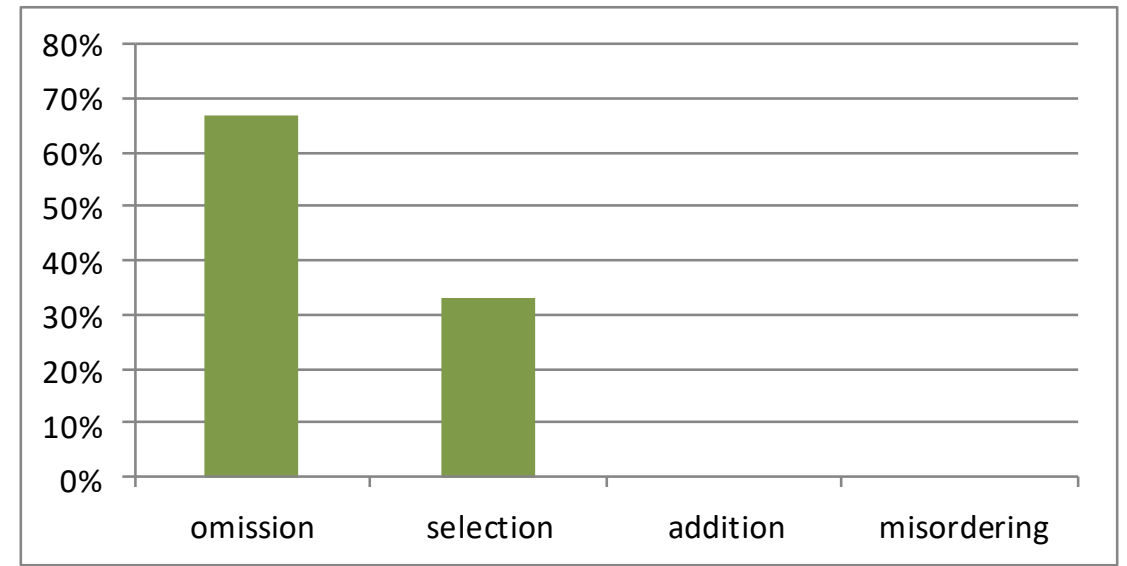

Figure 3. Errors in Using Cohesion

\section{Discussion}

This research was aimed at finding out the types of lexical and grammatical cohesion used in thesis abstract written by English Department students of Universitas Bengkulu in the period 2017 to 2019 and also to find the error of using cohesion devices. This research focused on describing the types and the error found in theses abstract written by English department students in the period 2017 to 2019. The researchers will explain the percentage of cohesion use and error in their use as well. The sample of this research were 30 theses 
abstracts which were taken randomly by the researcher, and to get the data, checklist was used.

In line with the result of this research, we can see that every thesis abstract contains cohesion devices in it, both grammatical and lexical. There are six types of lexical cohesion found in this research, they are Repetition, Synonymy, Antonymy, Hyponymy, Meronymy and Collocation. The most dominant of lexical cohesion is repetition with 269 times. According to the theory by Halliday and Hasan (1976), repetition is usually used as a sign of an important word or keyword of a text. The purpose of using repetition in thesis abstract is to stress something important repeatedly, so it makes the reader stay focus on the topic of discussion and also it will make the reader easy to understand what the writer want to explain. The last position of lexical cohesion found in this research are occupied by synonym and antonym. Simply, synonyms are relationships between words that have the same meaning and antonyms are relationships between words that have opposite meanings (Halliday and Hasan, 1976).

The similarities with previous studies can be found in this result of research. Saputra (2019) in his research entitled "An Analysis of Lexical Cohesion Types Used in The Discussion Section of Thesis Organized by English Study Program Students at Bengkulu University" found that as same as this study, the most dominant of lexical cohesion is repetition and the last is synonym and antonym.

Both of the studies have been done in non-native country and gain the same result. Since English is a foreign language in Indonesia, based on the previous study also, synonym and antonym is infrequently used in writing a text. This is not always related to the lack of vocabulary which being a problem in non-native countries. AsSeal (1991) said, there was even a period when "too much vocabulary learning was re-garded as a positively dangerous". This means even though learners have a rich repertoire of English words, they might not be able to pro-duce coherent sentences to convey idea.

Meanwhile, there are four grammatical cohesions found in this reseach, they are Reference, Conjunction, Ellipsis and Substitution. The most dominant cohesion is reference with 550 times. Demonstrative reference is the common type that is used in this research. Demonstrative reference is reference by means of location, on a scale of proximity (Haliday and Hasan, 1976). Although most abstracts contain more than 10 references as the cohesion type, there is still one abstract that contains only 8 references, but, same as the other abstract, this abstract dominantly used Demonstrative reference. 
The last grammatical cohesion is substitution. Both of ellipsis and substitution are not many found in this study because the corpus is thesis abstract which is a short text, so it does not require a lot of substitution and ellipsis to simplify the sentence. In study by Dr. Joseph Benjamin Archibald Afful and Mark Nartey (2014) underr the title "Cohesion in the Abstracts of Undergraduate Dissertations: An Intra-disciplinary Study in a Ghanaian University", they found the same as this study that reference is preponderantly used and substitution is the last one.

Rahman (2013) stated about research that reveals writing as a skill, should be tackled in a totally different way. Writers and teachers at English Department of Universitas Bengkulu should devices another strategy to makes their learners to be competent in writing a cohesive text. In this current research, the researcher found some problems that students face when writing a text in English especially in using cohesion devices, which are : 1.) The overuse of certain types of cohesion. In this research, for example, the students use repetition and reference too often, while ignoring the other types. This overuse of particular cohesion types will make the text looks boring. 2.) The students look unfamiliar with all types of cohesion devices, so they only use several types that they are familiar with because they find them easy to implement.

Based on the study by Rahman (2013), the overuse of certain types of cohesion devices implied that the students and teachers are in urgent need of being taught how to think in English while writing in English rather than thinking and preparing their ideas in mothertongue language and then transfering them into English. The teacher also have to focus on the way cohesive devices are used in other texts written by native speakers where a demonstration of all those devices is made in manifest in writing. It means that teacher should not only teach the student how to write using cohesion devices but also teach them to read a text written by native speaker to make them become familiar with the crucial role of cohesion. As Heller (1995) and Hirvella (2004) said that to enhance students' awareness of cohesion, it is essential to incorporate reading activities into writing classes. This enhances the students' awareness of the characteristic of good writing, including cohesion.

This reseacrh also aims to find out the errors of using cohesion devices. From the total 1.241 cohesion devices found in thesis abstract, there are only three errors found by the researcher. The errors only found in the use of lexical cohesion. The type of error is omission and selection, where omission means leaving out an cohesion that is needed to make the sentence correct and selection is error in selecting word in a sentence. Calculated from the 
number of comparison between cohesion devices and their errors, it can be concluded that the thesis abstract written by English Department Students of Universitas Bengkulu is in the percentage of $99.76 \%$ good.

However, the errors should be minimized by the students. In this research, all of the errors is the use of conjunction. Li Bin (2009) analyzed the writings through qualitative analysis of cohesion devices and he found many cohesive problem is in the use of conjunction. Meanwhile, Hidayati (2014) in her research also found some error of using conjunction. It means, the use of conjunction that we think is very easy, but in fact we still found errors in their use. Ngalimudin (2016) found 48 errors of conjunction in 30 argumentative texts and the most dominant error is the use of "and". This study proves that errors in the use of conjunction not only occur in English text but also in Indonesia text.

The error in using conjunction indicates that students do not understand how to use them. The students only understand about the concept of conjunction, it can be seen from the types of conjunction which was used in their thesis abstract, there are additive conjunction, adversative conjunction, causal conjunction and temporal conjunction, but in practice they still made errors in the use of conjunction.

Students and teachers must pay attention to the use of conjunction since it is a part of cohesion, and the error of using conjunction will affect quality of writing. As Mc'Culley (1985) said that cohesion is a key strategy for coherence and it plays an important role in the quality of writing. It means that the students have to mastering cohesion if they want to write a good text.

In short, the types of lexical and grammatical cohesion used in Undergraduate English Students' Thesis Abstracts of Universitas Bengkulu are similar with the previous study which has been done in other universities. The overuse of certain types of cohesion was still found. It means that students look unfamiliar with all types of cohesion. The errors that has been found by the researchers were only three errors. However, the error should be minimized by the students since cohesion is a key strategy and plays important role in the quality of writing.

\section{Conclusion and Suggestion}

\section{Conclusion}

After doing the research and analyzing the types of lexical and grammatical cohesion and its error in the thesis abstracts written by undergraduate English Students of Universitas Bengkulu in the period 2017 to 2019, several conclusions can be drawn from this study. 
It was found that there were six types of lexical cohesion found in thesis abstracts written by undergraduate English Students of Universitas Bengkulu in the period 2017 to 2019, the most dominan is Repetition, the second is Collocation, the third is Meronymy followed by Hyponymy in the fourth place. The last is Synonymy and Antonymy with the same number and percentage.

Meanwhile, the researchers found four types of grammatical cohesion used in thesis abstracts written by undergraduate English Students of Universitas Bengkulu in the period 2017 to 2019, the most dominant is reference, the second is conjunction, the third is ellipsis and the last is substitution.

For the third research question which is the error of using cohesion, the researchers found from the total number of 1.241 cohesion there are only three errors, they are two omissions of conjunction and one selection of conjunction. It can be concludes that thesis abstracts written by undergraduate English Students of Universitas Bengkulu in the period 2017 to 2019 is in the percentage of $99.76 \%$ good.

\section{Suggestion}

After conducting this research, the researchers would like to give some suggestions as follows : lecturers especially who teach Discourse Analysis and Writing, it is expected to provide more detailed explanation about how to apply cohesion appropriately so that in the future it can minimize the errors made by students in writing a text. Teacher also can motivate the students to enlarge their vocabulary which will help them to use synonymy, antonymy and the other cohesion types. For students who want to conduct a research, they have to know the importance of using cohesion in writing is to make the text easier to understand by the readers. Besides knowing the types of cohesion, students are also advised to understand how to use them appropriately, spesifically for conjunction because in this research, all of the errors found by the researcher are errors of using conjunction. They will also expected to use types of cohesion evenly so that no one type dominates because it will makes their writing look boring. The researchers suggest that future researchers specifically dealing with lexical and grammatical cohesion should take another part of thesis or they can also investigate the other writing text for example journals or articles. Hopefully, the future researchers will find other research questions and other ideas relating to English language teaching and learning processes. 


\section{References}

Afful,J.B.A and Nartey,M. (2014). Cohesion in the abstract of undergraduate disertation : An intra-disciplinary study in a ghanaian university. Journal of ELT and apllied linguistics (JELTAL).

Almutairi. (2017). Discourse analysis of cohesive devices in Saudi student's writing. World Journal of Educational Research. 4(4).

Ary, D, Lucy C and Chris S. (2010). Introduction to research in education. USA : Wadsworth.

Cresswell, J. (2002). Educational research. Lincoln: University of Nebraska.

Gay, L.R. (1987). Educational research : Competencies for Analysis and Application. London : Merril Publishing Company.

Gholami and Alizadeh. (2017). A Contrastive study of lexical cohesion in introduction in research articles: Native English and Iranian applied linguistics. Journal of Applied Linguistics and Language Research. 4(8), 307-316.

Halliday, M.A.K. \& Hasan, R. (1976). Cohesion in English. London : Longman.

Heller, M. (1995). Reading-writing connections : from theory to practice. USA : Longman Publisher.

Hidayati. (2014). Mistakes And Error Analysis Of Cohesive Features In Argumentative Essay Of Fifth Semester Students Of English Department Of Jambi University. Jambi : FKIP UNJA

Hirvella, A. (2004). Connecting reading and writing in second language writing instruction. Ann Arbor : University of Michigan Press.

Klimova and Hubacova. (2014). Grammatical Cohesion in Abstracts”. Czech Republic : University of Hradec Kralove.

Li Bin. (2009). Analysis of errors in the use of cohesive means of English Writing. Science and technology information.

Malah, Z. (2015). Lexical cohesion in academic discourse: exploring applied linguistics research articles abstracts. Yobe State University Damaturu, Nigeria.

McCarthy, M. (1991). Discourse Analysis for Language Teachers. Cambridge : Cambridge University Press.

McHugh, M. (2012). Interater reliability : The Kappa statistic. California : Brochemia Medica.

Ngalimudin, M.E. (2016). Analisis kesalahan penggunaan konjungsi dalam karangan argumentasi siwa kelas X SMA N Gondangrejo. Surakarta : FKIP UMS.

Noermanzah, N., Syafryadin, S., Castrena, O. W., \& Abid, S. (2020). Rhetoric structure of the master of ceremony and the function of the akikah event in Lubuklinggau City. Journal of English Education and Teaching, 4(2), 232-247.

Noermanzah, et al. (2020). The rhetorical structure of the Lubuklinggau Mayor's speech in building community trust. International Journal of Progressive Sciences and Technologies (IJPSAT), 19(2), 146-154.

Nurman,R, Arsyad S and Zahrida. (2019). Discourse markers in argymentative essay by the English education study program's students of Universitas Bengkulu : A Crosssectional Study. Journal of English Education and Teaching. 3(1).

Paltridge, B. (2012). Discourse analysis : An Introduction. Bloomsbury Publishing.

Rahman, Z.A. (2013). The use of cohesive devices in descriptive writing by Omani Studentteachers. Sage Open.

Rahmawati, I. N., Syafryadin, S., \& Widiastuti, R. (2019). Teaching Narrative Writing Using Freaky Fables Game: An Experimentation. English Education: Jurnal Tadris Bahasa Inggris, 12(2), 147-155. 
Salkie, R. (2001). Text and discourse analysyis. London and New York : Routledge.

Saputra, D. (2019). An Analysis of lexical cohesion types useed in the thesis discussion section of thesis by English study program students at Bengkulu University. Bengkulu : FKIP UNIB.

Seal, B. D. 1991. Vocabulary learning and teaching. In Celce-Murcia, M. (Ed.), Teaching English as a second or foreign language. Boston: Heinle \& Heinle

Suwandi. (2015). An Analysis of lexical cohesion types used in the discussion section of thesis organized by English study program students at Bengkulu University. Indonesian Journal of Applied Linguistics, 5(2), 253-26.

Syafryadin, I. N. R., \& Widiastuti, R. (2013). Improving grade X students' speaking achievement under Round Robin technique. International Journal on Education, 1(1).

Syafryadin, W., \& DEC, A. Noermanzah.(2020). Maxim Variation, Conventional, and Particularized Implicature on Students' Conversation. International Journal of Scientific and Technology Research, 9(2).

Syafryadin, S. (2020). Students' strategies in learning speaking: experience of two indonesian schools. Vision: Journal for Language and Foreign Language Learning, 9(1), 34-47. doi:http://dx.doi.org/10.21580/vjv9i14791 